\title{
ALUMÍNIUM PALACKOK NYAKAZÁSI LÉPÉSEINEK ÉS STABILITÁSVESZTÉSÉNEK MODELLEZÉSI SAJÁTOSSÁGAI
}

\author{
Gönczi Dávid \\ adjunktus, Miskolci Egyetem, Müszaki Mechanikai Intézet \\ 3515 Miskolc, Miskolc-Egyetemváros, e-mail:mechgoda@uni-miskolc.hu \\ Baksa Attila \\ egyetemi docens, Miskolci Egyetem, Müszaki Mechanikai Intézet \\ 3515 Miskolc, Miskolc-Egyetemváros, e-mail: mechab@uni-miskolc.hu \\ Kiss László Péter \\ adjunktus, Miskolci Egyetem, Müszaki Mechanikai Intézet \\ 3515 Miskolc, Miskolc-Egyetemváros, e-mail:mechkiss@uni-miskolc.hu
}

\begin{abstract}
Absztrakt
Az aluminium csomagolóeszközök elöállitása során az egyik kulcsfontosságú kérdéskör az alakitóerök és az alakitási határállapot -azaz ahol a palack stabilitásvesztése bekövetkezik-vizsgálata. A dolgozat ezen alakadási lépések, továbbá az ezek közben bekövetkezö stabilitásvesztést leiró egyenletrendszert és annak végeselemes megoldási kérdéseit tárgyalja. A feladat vizsgálatához kialakitottunk egy térbeli héjmodellt, amely a modálanalizis eredményeiböl kiindulva alkalmas a lengésképek alapján megzavart geometria nemlineáris stabilitásvesztési vizsgálatára módositott Riks-módszer segitségével.
\end{abstract}

Kulcsszavak: aluminium palack, stabilitásvesztés, alakitóerök, végeselem, héj

\begin{abstract}
The most critical questions in the production process of aluminium cans are the calculation of the reaction forces and the determination of the limitations for the forming steps where the loss of stability occurs. This paper investigates the system of differential equations of this stability problems and its solution with finite element analysis. A three-dimensional model is considered using shell elements, where the ideal geometry is perturbed by the scaled displacement field coming from the combinations of the eigenshapes. The strongly nonlinear stability problem is solved by the modified Riks algorithm.
\end{abstract}

Keywords: aluminium can, stability, reaction forces, FEA, shell

\section{Bevezetés}

Az utóbbi években nagymértékben megváltoztak az alumínium csomagolóeszközök piacán felmerülő igények, ami azt jelenti, hogy a különböző termékgyártók marketing szempontok alapján megfogalmazott újszerü geometriával rendelkező aeroszolos palackalakok gyártását igénylik. Az új formavilág hatékony tervezéséhez indokolt a csomagoló eszközök jelenlegi gyártásának, a technológia kritikus müveleteinek részletesebb numerikus szimulációval történő vizsgálata, illetve a kísérleti úton történő validálása. Az aeroszolos palackok geometriájukból adódóan - a falvastagság/átmérö viszonyszám alapján, ami a konkrét feladatoknál 1/100-os nagyságrendü - vékony héjszerkezeteknek tekinthetők. A falvastagság sok esetben a paláston jó közelítéssel állandónak vehető. Kísérleti tapasztalat, hogy különféle geometriákon elvégzett mérések során a kritikus erő, vagy feszültség (aminél bekövetkezik a kihajlás) rendszerint nagy szórást mutat. Ezt a jelenséget Koiter [1] tudta elsőként hitelesen megmagyarázni. Koiter állítása szerint a mérési eredmények szórásának oka a szemmel nem látható geometriai imperfekciók (hibák, tökéletlenségek) hatása. A különféle, változatos 
hibák, amelyek a gyártás (tömeggyártás) során alakulnak ki, azt eredményezik, hogy igen széles mezőben szórnak az eredmények. Vagyis mondhatjuk, hogy egyes héjszerkezetek (és általában a héjszerkezetek jelentős része) érzékeny az imperfekciókra, hatásuk tehát jelentős lehet a kritikus erőre (feszültségre).

Vékony falú hengeres testek stabilitásvesztéséről számos tanulmányban olvashatunk. A munkák jelentős része részletesen foglalkozik a stabilitásvesztést befolyásoló tényezőkkel, közöttük is az egyik legjelentősebbel, a geometriai imperfekció hatásával hengeres héjak esetén [2-7]. Ezen cikkek (föként rozsdamentes acélból készült) hengeres testek horpadásaiból és egyéb gyártási hibáiból származó alakhibák, illetve azok méretének és elhelyezkedésének hatásával foglalkoznak egyszerü geometriájú szerkezeti elemek stabilitásvesztése során. A [8] és [9] cikkek az axiálisan terhelt alumínium palackok (föként üdítőitalos palackok) teherbírásnak végeselemes vizsgálatával foglalkoznak, illetve az alakhibák hatásának terhelhetőségre gyakorolt hatásával. Belblidia munkái $[10,11]$ az alumíniumból készült aeroszolos palackok töltőnyomás alatti viselkedésével és stabilitásvesztésének nemlineáris numerikus szimulációjával foglalkoznak.

Az aeroszolos palackok gyártásának és alakadásának numerikus vizsgálatát több cikk is célul tüzte ki [12-16], amelyek a gyártási folyamat különbözö fázisainak és a végtermék egyszerü numerikus vizsgálatával foglalkoznak, kezdve az előgyártmányból (pogácsából) való hátrafolyatástól az alakadás fázisainak vizsgálatáig.

Jelen cikk az alumínium csomagolópalackok gyártási lépéseinek numerikus szimulációjával, az alakítóerők és a stabilitásvesztés jelenségének vizsgálatával foglalkozik.

\section{A palackgyártás technológiája}

Az alumínium aeroszol palackok gyártása speciális gyártósoron történik, amelynek főbb technológiai müveletei:

- képlékeny hidegalakítás: amely során a kenőhengerekben megkent tárcsákat (pogácsákat) hátrafolyatják. A folyató-bélyegről a szegmenses lehúzó távolítja el a folyatott darabot, az ún. csészét, amelyet egy kar tol el a bélyeg útjából, és a következő müveletet végző egységhez kerül. Ez a lépés azért is lényeges, mert a további müveletekhez megfelelő falvastagság eloszlást kell létrehozni.

- A folyatott darabot ezután méretre vágják, majd eltávolítják a felületre ragadt szemcsedarabokat és kenőanyagot.

- Lakkozás: az előkészített darab külső és belső felületét megfelelő minőségü lakkréteggel látják el, amely védi a palack felületét a szennyeződésektől, korróziótól, esztétikai szempontból is fontos és a festékréteg is erre kerül fel rögtön utána. A külső lakkozást több lépésben viszik fel a csomagolópalack felületére, majd a lakkréteget megadott hőmérsékleteken és időtartamig beégetik. Ebben a lépésben a hátrafolyatás során keletkező maradó feszültségek jelentősen csökkennek.

- Nyakbehúzás, tágítás/szükítés: ahol az eddigiekben előkészített darab több lépésben (általában 3040 lépésben) elnyeri végső alakját.

- Az utolsó lépésekben forgácsolják a palackok száját, majd következik az ellenőrzés és a csomagolás.

A palackok alakja nem lehet tetszőleges, hiszen a nyakbehúzó gépen az alakítási részmüveletek száma véges, és bizonyos geometria alakítása esetén a darab tönkremegy. Így tehát az alakítási határállapot meghatározása kiemelten fontos a csomagolópalackok tervezése során. Ennek egyik leggyorsabb és leghatékonyabb módja numerikus szimuláció, azon belül is végeselem módszer alkalmazása.

Innen már látszik, hogy az alakadás, avagy nyakazás vizsgálatára hatással van az azt megelőző müveletek technológiai paraméterei. Így a különféle palackok szimulációjánál meg kell vizsgálni a hátrafolyatásból származó maradó feszültség hatását, illetve annak változását a következő, lakkbeégetési mủvelet után is. Figyelni kell a héj vastagságának változására is, és az figyelembe venni az alakítási lépések előtt és között is. 


\section{A feladat leírása}

A számításokhoz szükségünk van az anyagjellemzők meghatározására. A vizsgált, gyártásban lévő aeroszolos palackok A199.5 (EN AW 1050) jelü anyagból készülnek, külső- és belső felületükön festékréteggel és lakkal vannak ellátva. Mérlegelni kell, hogy lehet-e ezeknek a rétegeknek érzékelhető hatása a mechanikai viselkedésre. Az alumínium legfontosabb mechanikai jellemzői a következők: rugalmassági modulusz: $75000 \mathrm{MPa}$, Poisson tényező: 0,33, sűrüség: $2,7510^{-9} \mathrm{t} / \mathrm{mm}^{3}$, folyáshatár: $120 \mathrm{MPa}$, szakítószilárdság: $150 \mathrm{MPa}$.

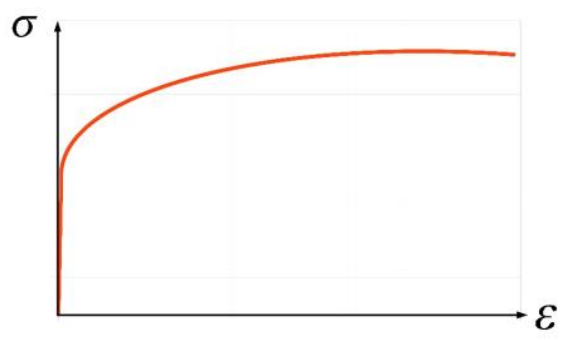

1. ábra: Az alumínium szakítódiagramja

Ami az anyagi karakterisztikát illeti, egy jelleghelyes szakítódiagramot (egytengelyü nyúlásfeszültségi viszonyt) mutat be az 1. ábra. Ezt két tartományra osztjuk: az első egy lineárisan rugalmas szakasz, ahol a feszültség és az alakváltozás mértéke egyenes arányban áll egymással, amely szakaszra tisztán csak a lineáris perturbációs módszereknél lesz szükségünk a továbbiakban, a második pedig a (törésponttól kezdődően) a képlékeny tartomány. Mivel a palackok alakítására az utóbbi tartományban kerül sor, mindenképpen rugalmas-képlékeny anyagmodellt kell alkalmaznunk. Ugyanakkor megjegyzendő, hogy a kihajlás jellemzően a rugalmas tartományban indul meg [17]. Az egyes anyagjellemzők katalógusból, illetve méréssel határozhatók meg. A kísérletekre (pl. a palack különböző zónáiból származó próbatestek szakítóvizsgálatára) azért is van szükség, mivel a hátrafolyatás során az előgyártmány nagy mértékü nyúlást szenved, amely különböző anyagi viselkedéshez vezethet a palack különböző pontjain. Mérések alapján a folyásgörbe a hátrafolyatott darab alakítására jellemző tartományában jó közelítéssel lineárisnak tekinthető.

Az anyag viselkedésére hatással lehet többek között az alakítási sebesség, a hőmérséklet, a hőkezelés és a kezdeti feszültségek is. A feladat erősen nemlineáris jellegü, ugyanis az anyagi nemlinearitás mellett nagy alakváltozásról beszélhetünk és a palack alja érintkezik egy síklappal, ami miatt a kontaktegyenletek is megjelennek.

A végeselem programok alapvetően kétféle kontakt megközelítéssel - általános kontakt és felületpárok- és két fö algoritmussal - büntetőparaméteres és kinematikai/Lagrange multiplikátoros algoritmusok - dolgoznak. A szakirodalom szerint [18] általában elmondható, hogy az általános kontakt algoritmus gyorsabb, olcsóbb és jobban alkalmazható több test (szilárd és merevnek modellezett testek) alkotta vegyes rendszerek vizsgálatához. A numerikus szimuláció során ügyelni kell a héjak éleinek viselkedésére (pl. „bull nose” hatás kiküszöbölése) és a kontakt okozta stabilitási problémákra, így mi a büntetőparaméteres algoritmust használtuk.

$\mathrm{Az}$ alakítóerők számítását tekintve mind geometriában, anyagában, megtámasztásában és terhelésében látszólag forgásszimmetrikus/tengelyszimmetrikus problémához, azaz kétdimenziós feladathoz jutunk. Azonban ebben az esetben hátrány, hogy a kísérleti tapasztalatok alapján az ilyen modelleken nem végezhetők stabilitásvizsgálatok, a nem forgásszimmetrikus viselkedés miatt. Amire alkalmazható az az alakítóerők számítása. Továbbá ebben a kétdimenziósesetben a héjszerü geometria esetén a „locking” és „hourglassing” numerikus problémákra is oda kell figyelni, valamint az elemek torzulásával is számolni kell (és újrahálózást elöírni bizonyos esetekben), a kielégítő háló megnövelheti a rendszer szabadsági fokainak számát, így a futási időt is, ráadásul nem praktikus külön geometriai modell készítése az alakítóerők és a stabilitásvesztés számítására.

Ennél fogva, a geometria jellegéből adódóan a palackokat háromdimenziós geometriával vett 
vékony héjként modelleztük. Ez azt jelenti, hogy az eredeti háromdimenziós geometriát a középfelület leképezésével helyettesítettük, és minden pont egy normálist reprezentál a modellben, amely pontonkénti szabadsági fokainak száma általában 6. Ezzel egy háromdimenziós kontinuum modellhez képest nagyban lecsökkenthetö a numerikus modellezéshez szükség számítógépi erőforrás igény, miközben az eredmények megbízhatók maradnak. Lineáris és kvadratikus, három- és négy csomópontú héjelemeket alkalmaztunk, amelyek - még lineáris interpoláció mellett is, ha megfelelően nagy számban használjuk őket, azaz alkalmasan megválasztott kis elemmérettel- alkalmasak nagy alakváltozások leírására és egyúttal érintkezési feladatoknál is elfogadható eredményt adnak.

Az ideálisnak tekintett kiinduló palack geometriát megzavartuk - azaz mesterségesen alakhibával láttuk el - a modal analízisből nyert sajátalakok kombinációjával. A megzavarás mindig olyan mértékü volt, hogy az elöírt türésmezőn belül maradtak a vonatkozó méretek. A mérésekkel összhangban számos sajátalak-kombinációt kipróbáltunk, hiszen igencsak változatos - lényegében véletlenszerü - alakhibák jelentkeznek a valóságban és ezek közül a legkedvezőtlenebbet (legkorábban bekövetkező stabilitásvesztéshez tartozót) célszerü mérvadónak tekinteni, hogy gyártás során a selejt darabok száma minimális legyen.

Az elvi háttérről annyit szükséges megemlíteni [4], hogy minden testnek vannak úgynevezett saját-, vagy természetes frekvenciái és ezekhez tartozó sajátalakjai/lengésképei. A sajátfrekvenciákon való gerjesztés (rezgetés) hatására rezonancia alakulhat ki, ami tönkremenetelt okoz és az ekkor tapasztalható alakváltozást a frekvenciához tartozó lengéskép mutatja. A vonatkozó sajátalakok kibontásával igen változatos módokon lehet zavarást elhelyezni a tökéletes geometrián. Matematikailag egy sajátértékfeladat megoldásából nyerhetjük a keresett jellemzőket. A végeselem módszer segítségével lehetőség nyílik szerkezetek, így héjak sajátfrekvenciáinak, sajátalakjainak számítására. A program a rezgések frekvenciáit egy lineáris sajátérték-feladat numerikus megoldásából származtatja. Feltételezve, hogy ideális, csillapítatlan dinamikai rendszert vizsgálunk, a kérdéses sajátfrekvenciákat egy

$$
\left(\mathbf{K}-\omega^{2} \mathbf{M}\right) \cdot \boldsymbol{\varphi}=0
$$

alakú, diszkretizált feladat közelítő megoldásából származtatja a szoftver. Itt $\mathbf{M}$ a szerkezet tömegmátrixa, $\mathbf{K}$ a merevségi mátrix, $\omega$ a sajátkörfrekvencia és $\boldsymbol{\varphi}$ a sajátvektor (a csomóponti normált elmozdulásokat tartalmazó vektor). A sajátérték-feladat megoldására két iterációs technikát kínál fel a szoftver: altér iteráció és Lánczos-módszer. Ha nagy a vizsgálat tárgyát képező rendszer szabadságfoka, akkor numerikus hatékonysága miatt a Lánczos-módszer választása a célszerü [18, 19]. A megoldásként kapott $\varphi$ sajátvektorok normáltak, azaz a maximális elmozdulás értéke egységnyi. Ezt szükséges majd skálázni az adott palacknál érvényes türésmezőnek megfelelően.

Ami a további geometriát illeti, a fenékrésztől eltekintve a palackok falvastagsága állandónak tekinthetö, a fenékrésznél a méretváltozás esetenként szakaszonként folytonosan történt. A választott anyagmodell izotrop, lineárisan rugalmas, lineárisan keményedő, a hőkezelés utáni állapotban mért karakterisztikához igen jól illeszkedő. Mivel a kihajlás rendszerint a rugalmas tartományban kezdődik meg, így ez a lineárisan keményedő modell megfelelőnek bizonyul. A lineárisan rugalmas tartományban a feszültség-alakváltozás kapcsolatának leírása az alábbi képlet segítségével történik $[18,20]$ :

$$
\mathrm{D} \cdot \boldsymbol{\varepsilon}=\boldsymbol{\sigma}
$$

ahol $\mathbf{D}$ az anyagjellemzők negyedrendü tenzora, $\boldsymbol{\sigma}$ a feszültségi tenzor, $\boldsymbol{\varepsilon}$ pedig az alakváltozási tenzor. Az anyagjellemzők mátrixa két független anyagparaméterrel adható meg.

Az felépített modell geometriailag nemlineáris: nagy alakváltozásokat tételez fel és a Riks-módszer segítségével alkalmas az egyensúlyi utak kirajzolására. Ezekből olvasható le az alakító erő-elmozdulás kapcsolat és dönthető el, hogy mikor következik be a stabilitásvesztés, mikor érjük el az alakítási határállapotot. Szakirodalmi ajánlások alapján egyúttal célszerü első lépésben geometriailag lineáris modellel vizsgálódni, függetlenül attól, hogy az ilyen rendszerint túlbecsüli a megengedhető terhelést. A szoftver a lineáris probléma megoldásakor [19] feltételezi, hogy a tényleges terhelés valamilyen állandó referencia teher és egy terhelési paraméter szorzata. A szoftver által végzett számítás során egy homogén lineáris egyenlet-rendszerrel meghatározott

$$
\mathbf{K} \cdot \boldsymbol{\varphi}=0
$$


szerkezetü sajátérték-feladatot kell megoldani. Azonos az egyenletek és az ismeretlenek száma. A képletben álló szimmetrikus $\mathbf{K}$ mátrix a szerkezet merevségi mátrixa, $\boldsymbol{\varphi}$ pedig az (általánosított) elmozdulások csomóponti értékeit tartalmazó oszlopmátrix. A $\mathbf{K}$ mátrix a terhelési paraméter függvénye. A sajátérték-feladat megoldása elvben annyi sajátértéket (terhelési paramétert) eredményez, amennyi az egyenletrendszert alkotó egyenletek száma: a $\mathbf{K}$ mérete. Minden sajátértékhez tartozik egy (stabilitásvesztés utáni) sajátalak: a megoldást követően a $\varphi$ tartalmazza a stabilitásvesztés utáni alakhoz tartozó csomóponti általánosított elmozdulásokat. A megoldás során a terhelési paraméter változtatásával (növelésével) kapjuk meg az $i$. lépésben azt a terhelést, amelyre nézve szingulárissá válik a merevségi mátrix. A program futtatásakor az az alapvető feladatunk a geometriát és anyagminőséget leíró adatok bevitele mellett, hogy a héj megfelelő (elöre kiválasztott) pontjában/pontjaiban felvegyünk egy tetszőleges $P$ nagyságú (nem zérus) referencia terhelést, amit aztán a program a terhelési paraméter változtatásával (növelésével) addig léptet, amíg (minimális hibával) teljesül a fenti egyenlet. A kritikus erő az így adódó sajátérték és a $P$ szorzata.

$\mathrm{Az}$ alapprobléma igényesebb és ebböl kifolyólag pontosabb megközelítéskor (geometriai nemlinearitás esetén) sokat segít a szerkezet viselkedésének megértésében az erő-elmozdulás diagram megrajzolása [18], [19]. Ez valójában a szerkezet elsődleges egyensúlyi útját mutatja be az eröelmozdulás kapcsolat segítségével. Néhány jellemző példát mutat a 2 . ábra.

(a)

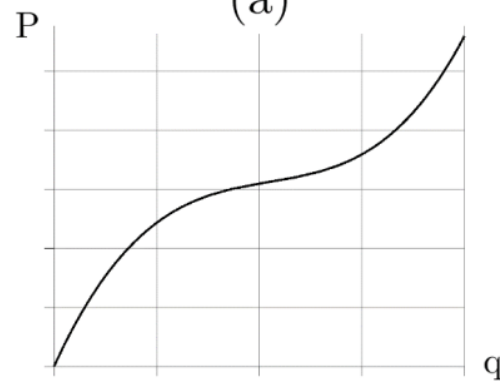

(c)

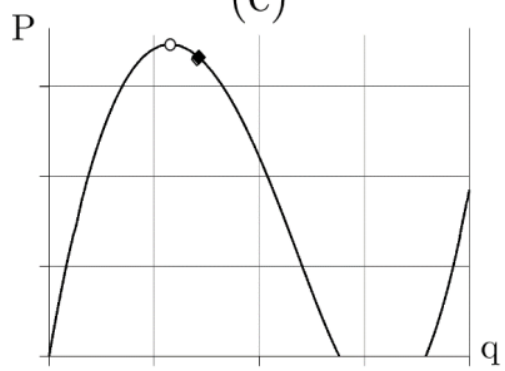

(b)

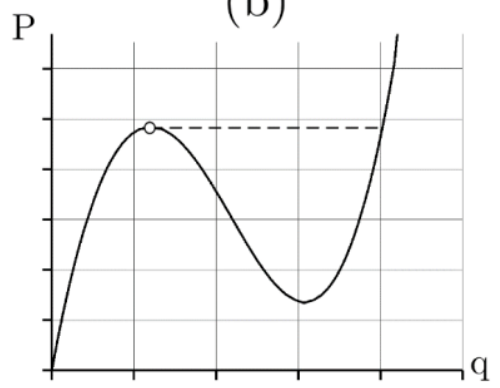

(d)

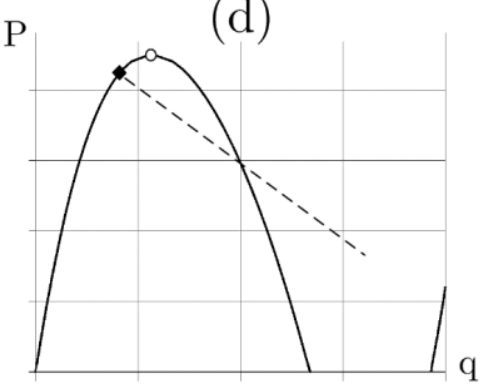

2. ábra: Néhány lehetséges erő-általánosított elmozdulás diagram [19]

A 2. (a) jelü ábra esetén bemutatott viselkedés nem jelent stabilitásvesztést. A (b) részleten, jellemzően tökéletes geometria esetén, bekövetkezik stabilitásvesztés: a kritikus terhelés elérésekor (üres karika) az elmozdulás hirtelen, nagymértékben megnő és ennek következtében hirtelen, horpadás jelentkezhet a héjon, mindenféle látható előjel nélkül. A (c) jelű részlet szerint továbbra is a lokális maximumpont elérésekor következik be a kihajlás, de ugyanakkor az elsődleges egyensúlyi úton megjelent egy további, bifurkációs pont is. A (d) részlet azt mutatja, hogy amennyiben a szerkezet rendelkezik geometriai imperfekciókkal, akkor a stabilitásvesztés az ideális esethez képest korábban, kisebb kritikus erőnél (feszültségnél), úgynevezett bifurkációs pontokban következik be - lásd a fekete szimbólumot.

A végeselemes módszerben az alkalmazott eljárás az ún. módosított Riks-algoritmus. Mint ahogy azt láthattuk az előző ábrán, geometriailag nemlineáris modelleknél gyakran előfordul, hogy az erő- 
elmozdulás diagram negatív merevségü szakaszokból is áll (másodlagos egyensúlyi utak). A Riksmódszer (szemben a hagyományos technikákkal) akkor is hatékonyan müködik, ha a probléma instabil, azaz a vizsgált rendszer viselkedése olyan, hogy az elmozdulás nő, miközben a terhelés csökken a megoldás elörehaladása során. Így a klasszikus megoldási módszerekkel (pl. NewtonRapson iteráció) nehézkes vagy nem lehetséges ezeket a stabilitásvesztési problémákat kezelni. A módszer lényege, hogy a problémát leíró eredeti nemlineáris egyensúlyi egyenleteket, amelyekben az erő és az elmozdulás az ismeretlenek, kiegészíti egy kényszeregyenlettel és ezek metszéspontját keresi meg, esetünkben a Newton-módszerrel. A kényszeregyenlet az egyensúlyi út ívhosszára vonatkozik, és azt keressük, hogy milyen erö-elmozdulás párnál alakulhat ki valamilyen előírt ívhossz. Az ívhossz ciklikus léptetésével a megoldás ponthalmazként adódik ki. A módszer egyik hátránya, hogy a bifurkációs pontokat nem találja meg, ehhez szükség van geometriai imperfekciók bevezetésére.

A végeselemes diszkretizálásnál (végeselem háló készítésnél) figyelnünk kell arra, hogy az elemek megfelelően kis méretüek legyenek és ne szenvedjenek torzulást, melyek numerikus instabilitást okozhatnak. Minden esetben több szimulációt (és konvergenciavizsgálatot is) célszerü végeznünk különböző elemfelosztásokkal -és néhány esetben eltérö elemtípussal- annak érdekében, hogy megbízható eredményeket kapjunk. Újrahálózásra menet közben általában nincs szükség, mivel az alakváltozás mértéke nem indokolja azt.

A 3. ábra szemlélteti egy tipikus szükítési lépés végeselemes modelljét. A zöld színnel jelzett szerszám és a piros színnel ábrázolt vasalótüske anyaguk és geometriájuk miatt merev testekként modellezendők és a kontaktfeladat miatt érdemes elemekre osztani őket (diszkrét merev felületként modellezni). Az alakítóerőt az alakító szerszám referenciapontjában tudjuk értelmezni, és az erőelmozdulás diagrammokhoz használjuk majd fel öket.

További vizsgálatokat kell végezni a palack megfogásának és a kinematikai/dinamikai peremfeltételek viszonyáról. Így például egy pneumatikus megfogás esetén az alsó perem tengelyirányú elmozdulását kötjük le, a palást megfelelő szakaszain pedig dinamikai peremfeltételt írunk elö.

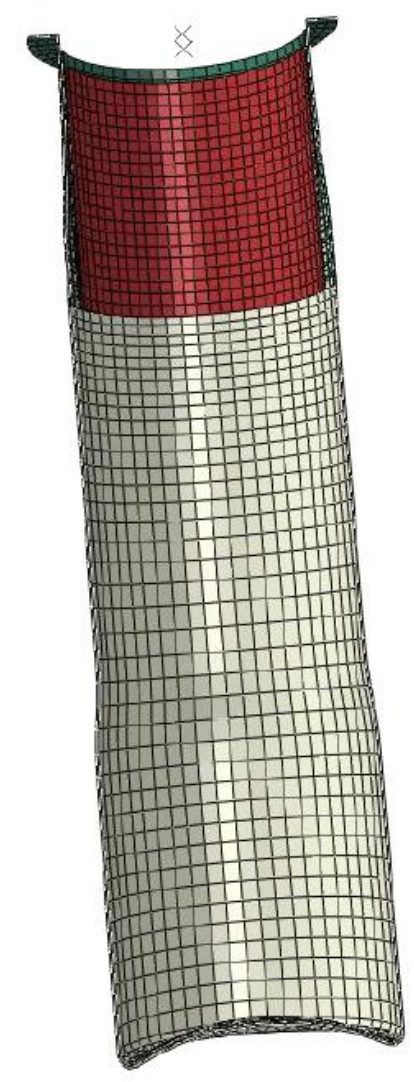

3. ábra: A nyakazási lépés modellje 
Kiszámolhatjuk az adott müvelet alakítóerő igényét, majd a stabilitásvesztést okozó erőt (az ún. roppantóerőt), és ezek összevetéséből tudunk következtetni az adott lépésbeli technológiai tartalékról.

\section{4. Összefoglalás}

A dolgozat az alumínium csomagolópalackok alakadási lépéseinek numerikus szimulációjának lépéseivel és azok hátterével foglalkozott. $\mathrm{Az}$ aeroszolos palackok vizsgálatára háromdimenziós geometria mellett héjelemeket és Riks-módszert használtunk. Vizsgáltuk a folyamatot leíró differenciál egyenletrendszert és annak végeselemes megoldási kérdéseit. Megadtuk, hogy a gyártási hibákat néhány jellemző lengéskép előállításával, majd ezek alapján a tökéletes geometria megzavarásával célszerü figyelembe venni. Felvázoltuk a végeselemes modellt az alakítóerők és a roppantóerők, azaz a stabilitásvesztéshez tartozó reakcióerők számítására.

\section{Irodalom}

[1] Koiter, W.T. The Stability of Elastic Equilibrium. PhD értekezés, Technische Hooge School at Delft, Delft, 1970.

[2] Chryssanthopoulos, M.K., Poggi, C. Stohastic imperfection modelling in shell buckling studies. Thin-walled structures 1995, 23:179-200. https://doi.org/10.1016/0263-8231(95)00011-2

[3] Hautala, K.T. Buckling reduction factors of stainless steel shell structures. Steel Construction Institute, 2003.

[4] Schneider, W. Stimulating equivalent geometrical imperfections for the numerical buckling strength verification of axially compressed cylindrical steel shells. Computational Mechanics 2006, 37(6):530-536. https://doi.org/10.1007/s00466-005-0728-8

[5] Prabu B., Bujjibabu, N., Saravanan, S., Venkatraman, A. Effect of a dent of different sizes and angles of inclination on buckling strength of a short stainless steel cylindrical shell subjected to uniform axial compression. Advances in Structural Engineering 2007, 10(5):581-591. https://doi.org/10.1260/136943307782417735

[6] Prabu, B., Raviprakash, A.V., Venkatraman, A. Neighborhood effect of two short dents on buckling behavior of thin short stainless steel cylindrical shells. International Journal of Computer Aided Engineering \& Technology 2009, 4(12). https://doi.org/10.1504/IJCAET.2012.045654

[7] Bala, P., Raviprakash, A.V., Rathinam, N. Parametric study on buckling behaviour of thin stainless steel cylindrical shells for circular dent dimensional variations under uniform axial compression. 2010.

[8] Sawant, D.A., Venkatesh, M.A. Buckling and crushing analysis of cylindrical aluminium cans \& optimizing the parameters effecting crush strength using FEM. International Research Journal of Engineering and Technology 2016, 3(6):32081-3085.

[9] Hegadekatte, V., Shi, Y. Buckling of beverage cans under axial loading. Simulia India Regional Users Meeting, 2011.

[10] Belblidia, F., Corft, N., Hardy, S.J., Shakespeare, V., Chambers, R. Simulation based aerosol can design under pressure and buckling loads and comparison with experimental trials. Materials and Design 2013, 52:214-224. https://doi.org/10.1016/j.matdes.2013.05.041

[11] Belblidia, F., Corft, N., Hardy, S.J., Bould, D.C., Sienz, J. Aerosol cans under pressure and buckling loads. Sustainable Design and Manufacturing 2014, 1:13-17.

[12] Hardy, S.J., Abdusslam, R. Finite element modelling of the manufacturing process for aluminium aerosol cans. Journals of materials: Design and Applications 2007, 221(4):265-274. https://doi.org/10.1243/14644207JMDA153

[13] Ceretti, E., Attanasio, A., Fiorentino, A., Giorleo, L., Giardini, C. Aluminium can shaping by hydroforming: simulative feasibility study and prototype production. The International Journal of Advanced Manufacturing Technology 2013, 68:1797-1807. https://doi.org/10.1007/s00170-0134978-x 
[14] Folle, L.F., Netto, S.E.S., Schaeffer, L. Analysis of the manufacturing process of beverage cans using aluminum alloy. Journal of Maerial Processing Technology 2008, 205:347-352. https://doi.org/10.1016/j.jmatprotec.2007.11.249

[15] Takeutshi, H. Numerical simulation technology for lightweight aluminium can. Journal of Material Processing Technology 1993, 38:675-687. https://doi.org/10.1016/09240136(93)90043-6

[16] Ceretti, E., Giardini, C., Attanasio, A. Comparison between simulative and experimental results of necking operations on aluminium can. Archive of IRIS, 12, 2005.

[17] Chen, T. On Introducing Imperfection in the Non-Linear Analysis of Buckling of Thin Shell Structures. Delft University of Technology Delft, the Netherlands, 2014.

[18] Abaqus 6.13 online documentation. Dassault Systems. 2015.

[19] Kiss, L. Síkgörbe rudak modellezése, végeselemes szimulációja az Abaqus kereskedelmi végeselemes szoftver segitségével. Oktatási segédlet. Miskolc, 2014.

[20] Gönczi, D. Speciális feladatok végeselemes modellezésének alapjai. Segédlet. Miskolci Egyetem, Miskolc, 2013. 